\title{
How Do We Recognize Recent Sexual Abuse in Children Less than 10 Years of Age? What Is the Role of Paediatric Wards? Experience in a French Paediatric Hospital
}

\author{
G. Picherot, N. Vabres, J. Fleury, E. Launay and C. Gras-Leguen \\ Clinique Médicale Pédiatrique, UAED, \\ CHU Nantes, \\ France
}

\section{Introduction}

A diagnosis of sexual abuse in children is being made increasingly in France and in all Western countries. Sexual abuses in France represent a third of all cases of maltreatment [1]. In children less than 10 years of age, discovery of the circumstances varies according to the situations experienced by the adolescents. Stories can involve silence or a revelation by indirect signs or consequences of abuses. To approach this diagnosis, we will successively address three aspects: the usual circumstances of the revelation or evocation of this diagnosis, a speech and behavioral side, and a clinical examination and its difficulties.

\section{Circumstances}

Generally, children under the age of 10 years are brought by their parents, and come more rarely with a social worker or forensic expertise.

A child's speech or a sudden change in behavior could disturb the relatives [2]. The diagnosis can be done in an environmental context of sexual assault: the revelation of a sibling or the child himself. It sometimes involves an investigation around an abuser or abnormal behavior of parents [2-3-4-5].

The evocation in less than three years old chidren may revolve around a child-minder, represented by doubt concerning behavioral or clinical abnormalities after returning home following a child-minding period, or more frequently, a situation evoking suspicion in the context of parental separation [6].

The diagnosis can be sought in circumstances of clinical abnormalities discovered by the parents or physician, as represented by suspicious perineal lesions or the consequences of sexual assault such as sexually transmitted disease atypical for the child's age [5].

The American Academy of Pediatrics established several factors which may lead to suspicion of sexual assault in children [7]: 
1. Declaration of the victim or witness (sibling, friend)

2. Questions for the family who suspects abuse

3. Discovery of direct or indirect suspect signs during a routine examination

4. Review requested by judicial authorities

In all cases, the evocation depends on the vigilance of the physician who receives the child [1]. Process of protection is possible if the child can be "heard" in those circumstances [7].

\section{The words and silent stories}

The interpretation of a word depends on the development and age of the child. The language of a child is structured between the ages of 4 and 6 years [8].

However, it is informative and based on cognitive and language development despite the age. "A young child of two years may report sexual abuse directly and clearly" [9]. The words are simple and correlated to the possibilities of the child. They sometimes refer to the act of aggression, and sometimes to the pain and consequent anxiety. They are called in special circumstances of personal hygiene, diaper or clothes changing, and sometimes during a clinical examination for instance when the child shows the assaulted area.

It is often a story without words, indirect consequences on the child's behavior may suggest the diagnosis. The subjective perception of one parent or the environment will lead to a discussion on recent changes. Many signs have been described as true indices [6], and often reflect the impact of recent trauma [9]:

- Fear: restlessness, irritability, insomnia, nightmares, screaming in front of a similar situation, feeling insecure

- $\quad$ regressive signs: refusal of parental separation, loss of developmental acquisitions

- painful reminders: refusal to change, to review

- $\quad$ somatic expressions: abdominal pain, anorexia, difficulty in swallowing

- indirect expressions of genital and perineal trauma: regression of cleanliness, appearance, constipation or faecal incontinence, voiding dysfunction revealed by urinary tract infections, sometimes up to Hinman syndrome or severe bladder dysfunction. [10]

- $\quad$ sexually transmitted diseases in spite of age will be discussed in terms of a clinical examination

- sexualized behavior: compulsive masturbation, precocious sex play or sexualized gestures of the child on the adult or another child

- unusual or even aggressive behavior with people nearby

If the child speaks or if its behavioral consequences reveals an history of abuse, its interpretation requests a rigorous approach [2-12-7].

The first adult who received the confidence should look for an experienced professional within 2-3 days after the revelation.

There is no way for the physician to bring together suspected children and adults, even to observe the reactions of the child.

The collection of the child's speech must be done with consideration to avoid leading questions at any age as the predictive value of words is not related to age [12]. 
Professionals must link the interpretation of a child's speech with its emotional and cognitive development and remember that memory for detail is unstable. The perception of time is more revealing than a chronological relation of facts as many temporal expressions have no meaning for younger children [11]. Emotional factors are also significant: the child's fear related to unsuitable for any age experiences may inhibit expression.

Early sexualized behaviors of children are not in themselves proof of aggression. Within three years there may be "periods of intense masturbation" without a past sexual assault as sexual curiosity in young children is widespread [5].

Strategies for assessing the validity of the statements described by Yuille are hardly applicable in younger children [13].

At this age, repeted situations of interrogation lead to an even greater possibility for misinterpretation and this is an important argument for filmed audition strategies [5]. None of these signs as a consequence of trauma is a priori indicative of sexual assault, and only their association to the context will lead to the diagnosis.

The circumstances of abuse would lead to a discernment of different disorders of the child by its family. Extrafamilial abuse may lead to earlier recognition of changes in the child.

Situations of alleged sexual assault in connection with parental separation are increasingly frequent. The interpretation of anxious behavior after a weekend at the ex-spouse's home, or confusion with necessary care and intimate assaults may lead to repeated investigations and traumatic experiences. This is also the case in the same situations of actual sexual assault [1-5-7].

There is no way to support an instrumental evaluation.[14] The use of sexed dolls is very controversial: the method is not recommended in the assessment of Yuille [13], and is to be used with great caution and interpretation by experts as reported by August [15]. The child can use ordinary toys (Bear, Figurines) to stage events or to describe the assaulted body parts. Older children may use drawings to express themselves. Among younger girls (less than 5 years of age), this method rarely leads to get a direct word or a specific behavioral sign, but "gives the child to see and hear something of grave concern," [16] and we must therefore raise the possibility of sexual assault.

\section{Clinical examination}

Clinical examination of a child in circumstances of sexual abuse is difficult for a child of any age. Its interpretation requires a skill that will avoid repetition of intolerable procedures [17]. Misinterpretations are common, particularly in young children.

The legal and social services eagerly await objective evidence of sexual assault. However, this rarely leads to a review of the findings of abnormalities.

The work of Heger et al. and their analysis with a rigorous methodology of 2384 records shows that an abused child and clinical abnormalities are found in only $4 \%$ of cases [3]. In $96 \%$ of cases, the diagnosis is based on the child's words and on the circumstances. Without denying the importance of a clinical examination, it must be considered in the course of the child's assessment as an important and sometimes significant element specific to this age, but rarely as a contributing factor. 
Consultation, even on the basis of a court application, must be part of the caring process. The complete pediatric examination should resemble, as closely as possible, the usual consultations. Apart from the objective forensic aspect, it is also designed to detect a sexually transmitted disease and reassure the child and its family of the normality of the body as this participates in the repair process [1-2]. The review is integrated into the comprehensive pediatric examination and requires no sedation beyond exceptional cases of lesions requiring surgery.

The examination may be experienced by the child as a second attack if not conducted in a supportive manner: explanations are allways required. We must use language appropriate to the age of the child, and must ask the parents for the words they usually use to name the genitals [6].

The examination is performed at this age in the presence of a parent that is not suspected and another person (from the nursing team). In our experience, the physician should never examine the child alone. This fits into the general reception which will be discussed.

Instrumental help with a genital examination is discussed at this age: using a pediatric colposcope to improve the performance of the examination or consideration for some simple situations, including systematic use of a video colposcope for the discussion of lesions. The use of a catheter with balloon inflation for a better visualization of the hymen is unnecessary and traumatic at this age. Instrumental help requires expertise [3-18], and should be reserved for pubescent patients [20].

The urgency of the review is still under discussion. It is indisputable if the abuse was less than 72 hours ago. Between three and 15 days after the abuse, the examination must be made quickly. Beyond 15 days, the examination may be delayed [6-21].

J.A. Adams gives further indications of an emergency medical examination [20]:

- genital or anal pain or bleeding

- $\quad$ need for medical care or urgent intervention

- the child's particular concern about possible damage

The physical examination cannot be separated from the history of the child. The verbal responses or attitudes of the child during the examination must be carefully noted. Children sometimes give additional information during the examination of the genitals [1-2-20].

In practice, it is recommended that this review include apart from genital and anal examinations "a complete physical examination with emphasis on growth parameters and sexual development of children examined mucocutaneous rigorous, searching for traces of violence throughout the body and especially at the inner thighs and chest, as well as areas of support and restraint (neck, wrists, ankles) a review of the oral cavity in search of lesions dental and mucous membranes, as well as the tongue-an observation of child behavior during clinical examination" [1].

The clinical findings can be of three types:

- General clinical abnormalities

- Abnormal perineal genital or anal

- Sexually transmitted infections despite age or suspicious vulvitis (rarely specific apart from sexually transmitted infections) 
General clinical abnormalities are traumatic signs in non genital areas reflecting physical abuse (hematoma shoulders, trace of restraint on the limbs, oral mucosa lesion, etc.).

Genital anomalies are looked at in a girl of that age in a supine position in the attitude of the so-called "frog" [6-20-22]. Children less than three years of age can also be considered sitting or lying on the lap of an accompanying individual [6]. There is no need to touch and it should be painless. The examiner should have precise notions about normal anatomical variations [6-20] as the large variations of aspects of the hymen before puberty to avoid errors [22].

Adams classifies the aspect of girls' genital into 4 categories [20-23]:

- variants of normal

- damage caused by other medical conditions

- injury uncertain

- more specific lesions

Fifty lesions or situations are thus classified.

Among the specific lesions, we find direct acute injury (laceration, bruises) or injuries related to the penetration (bruises, cuts, lacerations, and even destruction of the hymen). Scarring may have a high specificity (scarring of the posterior fourchette).

Good knowledge of the circumstances and clinical aspects of genital trauma of a girl can distinguish sexual assaults [24].

The genitals of boys are examined by simple inspection.

Anal anomalies are sought by examination in the supine or sometimes prone position [1-620]. They can be distinguished by examining the simple assault suspect fissure cracks associated with frequent constipation, and are always sagittal. The interpretation of anal dilatation is difficult. Instances of anal dilatation isolated to a degree greater than or equal to two centimeters are regarded by Adams as unspecific [20]. Warts also have a low specificity [1]. The practice of rectal examination or anuscopy is not recommended as routine. Anuscopy under suitable conditions can allow a rare staging of lesions.

Sexually transmitted infections must be sought and treated. They sometimes reveal elements of sexual abuse. Vaginal swabs and blood tests are sometimes informative, particularly if the abuse was less than 72 hours ago or if there is a local sign (flow). They are regarded under the same conditions as for other ages. The preparation of the child is necessary. The use of local analgesia for blood sampling is required.

The analysis of sexually transmitted infections depends on the age of the child.

The transmission of certain germs may be perinatal.

The presence of gonorrhea in the genital, anal, or oral region should be considered suspect after the neonatal period according to Adams [20]. Non-sexual transmission has been demonstrated beyond this period by other authors [6-25].

The diagnosis of syphilis should suggest sexual abuse outside of a maternal-fetal transmission.

The presence of Trichomonas vaginalis (6 months) or Chlamydia trachomatis (after three years) is also very suspicious [1-6-20]. 
HIV transmission is theoretically possible, but exceptional with the waning of sexual abuse at that age. Maternal serology will eliminate maternal-fetal transmission [20].

Other transmissions are available: Papillomavirus, Herpes Hepatitis B, Hepatitis C, etc., but few are specific and are therefore of uncertain significance.

The sampling for forensic investigation involving the search for sperm, DNA identification, and a toxic syndrome (abuse under drug) is the subject of specific protocols for identification, storage, and transmission. Each country has determined these conditions, and hence they have a legal value.

Samples used to research sexually transmitted infections do not represent a consensus before puberty, and must be adapted to the circumstances:

- research of gonorrhea, Chlamydia trachomatis, Trichomonas vaginalis by culture and bacteriological examination

- indirect research techniques for chlamydia and gonorrhea by PCR have no forensic value and must be confirmed by bacteriological cultures [21]

- serology HIV, Syphilis, Hepatitis B, Hepatitis C, according to circumstances [2021].(Figure 1)

\begin{tabular}{|l|l|}
\hline Highly suggestive signs & Uncertain signs \\
\hline $\begin{array}{l}\text { Sexual contact shown by the presence of } \\
\text { semen }\end{array}$ & $\begin{array}{l}\text { Injury acute or scarring of the vulva } \\
\text { does not reach the hymen }\end{array}$ \\
\hline $\begin{array}{l}\text { Hymen injury } \\
\text { Acute: tear, bruise, abrasion } \\
\begin{array}{l}\text { Scarring: Total posterior tear (between } 4 \text { and } 8 \\
\text { hours) }\end{array}\end{array}$ & $\begin{array}{l}\text { Notch or partial thinning of the } \\
\text { posterior hymen }\end{array}$ \\
$\begin{array}{l}\text { Partial or total absence of hymen posterior } \\
\text { hotch or partial thinning of the posterior }\end{array}$ & $\begin{array}{l}\text { hymen } \\
\text { Lesion of the fourchette acute or healed }\end{array}$ \\
\hline $\begin{array}{l}\text { Important anal acute lesion or scar } \\
\text { Trichomonas after } 6 \text { month } \\
\text { Chlamydiae after } 3 \text { years } \\
\text { Syphilis (outside maternofoetal contamination) } \\
\text { HIV ( if seronegative mother) }\end{array}$ & Warts \\
\hline
\end{tabular}

Fig. 1. Signs and those suggestive of uncertain significance [1-20-22] 
Preventive treatment (Post Exposure Prophylaxis, PEP) is discussed at this age (prepubertal). There is no systematic chlamydia, trichomonas or syphilis, and assessment is based on laboratory diagnosis. HIV preventive treatment is evaluated according to the circumstances of the assault, and must be weighed against the disadvantages of treatment at this age. Serological surveillance in post-exposure is also tailored to the assessed risks [1-2021].

The conditions of reception of the child victim of sexual assault are important.

They must be appropriate for the child's age during the entire process. The interview and examination should not repeat the trauma, and the permanent presence of a third adult caregiver is essential. Repeated examinations are unacceptable [1]. The review cannot be limited to the technical expertise of forensic aspects. The pediatric home team must be competent to collect details of history, examine the child, make a differential diagnosis with other causes of behavioral or clinical features, request additional tests, and send the certificates to ensure the appropriate care of the children [1-20].

In France, the passing of a law on 17 June, 1998 recognized the status of the victimized minor with enhanced rights, including assistance at hearings, filmed bond hearings, and the interests of health care professionals being represented at hearings. The association "Voice of Children" offered care to children affected by sexual abuse, and led to the assistance for "permanence and home units Multidisciplinary forensic child sexual assault victims" [26]. This "permanence" must improve the reception of minors. For the entire process of an initial investigation, the child is supported in one place suitable for children and is located in a pediatric hospital structure. In this structure, the child can be heard, admitted in cases of emergency if necessary, can receive treatment for pain if samples are needed under suitable conditions, and receive assessment on a psychological level. Psychological and social support of the child may be arranged with the relevant partner agencies. Management of these hotlines is conducted jointly by Social Services, the judicial services of Inquiry, Hospital Trust and the Regional Agency of Hospitalization, and advocacy groups for child victims (The Voice of the Child).

In Nantes, following the Prosecutor of the Republic's request, minors meet at first a pediatric nurse who explains the steps and accompanies the children and their families. Judicial investigators are invited to the hospital for a hearing filmed session under suitable and specific conditions. The medical team (pediatricians, gynecologists, psychiatrists and psychologists, including a social worker), conducts the initial medical and psychological assessments as requested. These reviews and assessments can be deferred after evaluation of the emergency level and safety of the child.

The nurse and social worker with the medical team organize an assessment of the psychological and social development of the child even if no judicial action results.

This new organization, dating back more than a decade, now covers more than 40 French hospitals. It has been, and remains, controversial. The main criticism is the concept of proximity Clinical (Pediatric ward) and Forensic (Justice) which could lead to a mixture of roles.

Our experience is very close to that of the CAC (Child Advocacy Center). The studies of Edinburgh [27] and Smith [28] focused on young adolescents, but included children of these 
structures as incorporated into pediatric hospitals. Their experience showed better results not only for the assessment of speech in a clinical approach, but also in relation to the advice given to children and their families. The organization of monitoring is also facilitated by this approach [27]. In accordance with the recommendation of Edinburgh, we incorporated a role for pediatric nurses with a long experience in childcare.

Tishelman confirms the value of an integrative model and justice for the pediatric care of affected children by setting 6 goals in these structures [29]:

- $\quad$ Evaluate specific forensic aspects

- Assess the overall health and psychological trauma of child victims

- Assess risk factors of abuse to prevent recurrence

- Evaluate opportunities for protection, therefore need to protect children by hospitalization

- Provide the child and its family psychological and social care

- Make recommendations to the social and legal services concerning the needs of the child and family

All this confirms the value of an integrated pediatric and forensic approach. This attitude is reinforced by the importance of physical and psychological consequences observed in adults who have suffered sexual assault in their childhood. Early care of the child within a pediatric approach should help to avoid such troubling developments [30]. Tishelman also speaks of a particular population of children whose judicial evaluation has not confirmed the sexual assault. Those children who leave without a judicial conclusion after a grueling investigation should also receive monitoring and care [29].

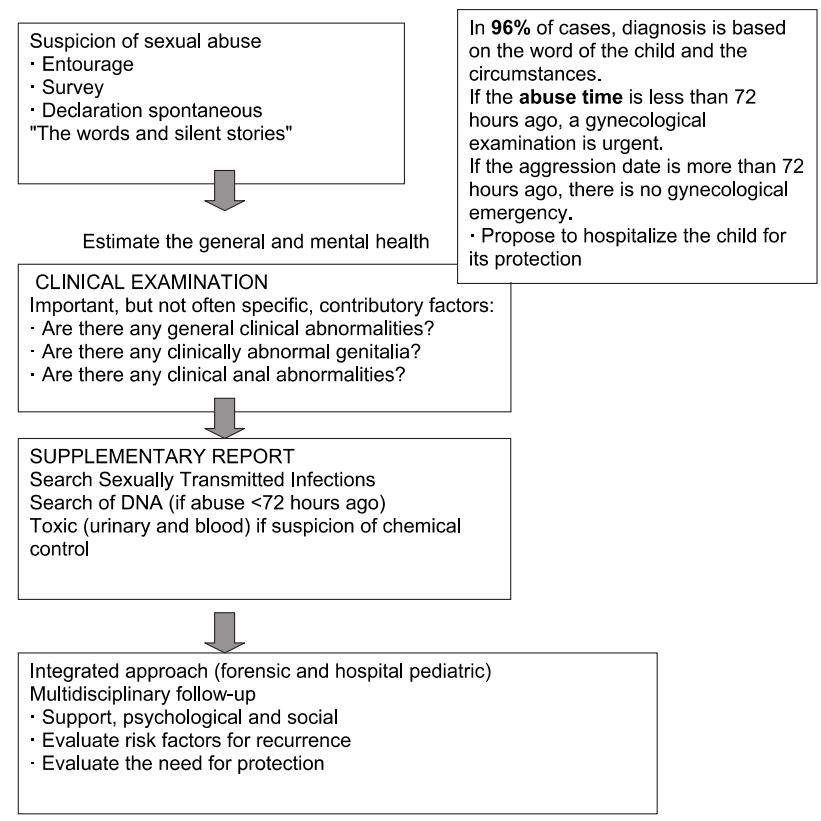


In conclusion, recognition of sexual abuse in children less than 10 years of age is based on the word of the child associated with indirect signs of a nonspecific nature. Clinical examination is essential, but it is difficult and rarely contributory. The forensic approach must be combined with an approach incorporating pediatric care and protection. The development of integrated units in forensic pediatric service for the reception of the whole child seems to us an essential change that will improve the entire process and prevent sequelae.

\section{References}

[1] Repérage et signalement de l'inceste par les médecins :reconnaître les maltraitances sexuelles intrafamiliales chez le mineur Haute Autorité de Santé France (HAS) 2011 www.has-sante.fr

[2] American Academy of Pediatrics Guidelines for the evaluation of sexual abuse of children: subject review. Pediatrics 1999;103:186-191

[3] Heger A, Ticson L, Velasquez O, Bernier R. Children referred for possible sexual abuse: medical finding in 2384 children. Child Abuse \& Neglect 2002;26:645-59

[4] Nathanson M., Muller MH., Belasco C., Dieu-Osika S., Camard O. Gaudelus J. Les enfants et adolescents victimes d'abus sexuels. Diagnostic et prise en charge. Arch Pédiatr 1998;5:84-9

[5] Van Gisenghem H - L'enfant mis à nu: L'allégation d'abus sexuel: la recherche de la vérité. Montréal Ed. 1999

[6] Frappier JY., Haley N., Allard-Dansereau Cl. Abus sexuels Ed. Les presses de l'université. Montréal 1990

[7] Kellog N. American Academy of Pediatrics Committee on Child Abuse and Neglect. The Evaluation of Sexual Abuse in Children Pediatrics. 2005;116:506-12

[8] Messerschmitt P. La vérité sort elle de la bouche des enfants? Arch Pediatr 2011;18:55-6

[9] De Becker E, Hayez JY. L'enfant en dessous de 3 ans maltraité sexuellement: comment les tout petits parlent d'un abus et comment y faire face? Neuropsychiatrie de l'enfant et de l'adolescence. 2003;51:105-10

[10] Garignon C., Mure PY, Parapel P, Chiche D, Mouriquand P. Dysfonctionnement vésicaux graves chez l'enfant victime de maltraitance: Le syndrome d'Hinman Press Med 2001;30:1912-23

[11] Roussey M, Balençon M. La valeur de la parole de l'enfant dans les situations d'abus sexuels. Rev Int Ped 1999;9-14

[12] Ceci SJ, Ross DF, Toglia MP. Age differences in suggestibility; psychological implications. J Exp Psychol Gen 1987;117:38-49

[13] Yuille JC. L'entrevue de l'enfant dans un contexte d'investigation et l'évaluation systématique de sa déclaration in L'enfant mis à nu Ed. Méridien Psychologie Montréal 1996

[14] Jodoin Cl. L'expert et ses outils in Us et abus de la mise en mots en matière d'abus sexuel Van Gijsegehm H Ed. Méridien Psychologie Montréal 1999

[15] August RL, Forman BD. A comparison of sexually abused and non sexually abused children's behavioural responses to anatomically correct dolls. Child Psychiatry Human Dev 1989;20:39-47

[16] Hayez JY. Sexual abuse of underage children: incest and extra-familial abuse. Psychiat Enfant. 1992;35:197-271 
[17] Makoroff K, Brauley J, Brandner A, Myers P, Shapiro R. Genital examinations for alleged sexual abuse of prepubertal girls: finding by pediatric emergency medicine physicians compared with child abuse trained physicians. Child Abuse \& Neglect 2002;26:1235-42

[18] Balençon M, Roussey M. Examen et conduite à tenir chez le jeune enfant victime d'abus sexuels. J Pédiatr Puericulture 2000;13:36-42

[19] Palusci VJ, Cyrus TA. Reaction to video colposcopy in the assesment of child sexual abuse. Child Abuse \& Neglect 2001;25:1535-46

[20] Adams JA, Kaplan RA, Starling SP, Mehta NH, Finkel MA, Botash AS, Kellog ND, Shapiro SA. Guidelines for medical care of children who may have been sexually abused. J Pediatr Adolesce Gynecol 2007;20:163-72

[21] Bernard D, Peters M, Makoroff K. The evaluation of suspected pediatric sexual abuse. Clin Ped Emerg Med 2006;7:161-9

[22] Myhre AK, Mykelstad K, Adams JA. Changes in genital anatomy and microbiology in girls between age 6 and age 12 years: a longitudinal study. J Pediatr Adolesc Gynecol 2010;23:77-85

[23] Adams JA. Medical evaluation of suspected child sexual abuse. APSAC Advisor 2010;22:2-7

[24] Benjamins LJ. Genital trauma in pediatric and adolescent females. J Pediatr Adolesc Gynecol 2009;22:129-33

[25] Goodyear-Smith F. What is the evidence for non-sexual transmission of gonorrhea in children after the neonatal period? A systematic review. Journal of Forensic and Legal Medicine 2007;14:489-502

[26] La Voix de L'Enfant: Permanences et unités d'accueil médico-légales pour les enfants victimes de Violences Sexuelles France 2002 www.lavoixdelenfant.org

[27] Edinburgh L, Saewy E, Levitt C. Caring for young adolescent sexual abuse victims in a hospital-based children's advocacy center. Child Abuse \& Neglect 2008;32:119-26

[28] Smith DW, Witte TH, Fricker-Elhai AE. Service outcomes in physical and sexual abuse cases: a comparison of child advocacy center-based and standard services. Child Maltreat. 2006;11:354-60

[29] Tishelman AC, Meyer SK, Haney P, McLeod SK. The clinical-forensic dichotomy in sexual abuse evaluations: moving toward an integrative model. J Child Sex Abus. 2010;19:590-608.

[30] Bouchard EM, Tourigny M, Joly J, Hébert M, Cyr M. Les conséquences à long terme de la violence sexuelle, physique et psychologique vécue dans l'enfance. Revue d'épidémiologie et de santé publique 2008;56:333-44 


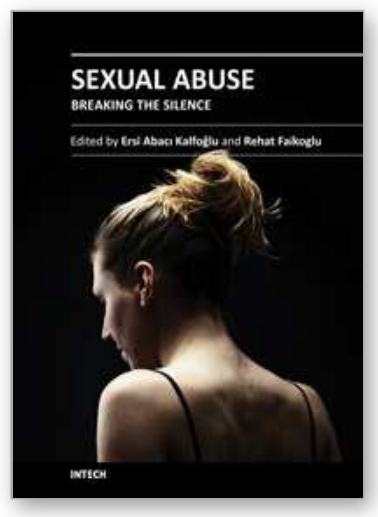

\author{
Sexual Abuse - Breaking the Silence \\ Edited by Dr. Ersi Abaci Kalfoğlu
}

ISBN 978-953-51-0425-4

Hard cover, 238 pages

Publisher InTech

Published online 23, March, 2012

Published in print edition March, 2012

Sexual assault can be considered as expression of aggression through sex. This, in turn, can have serious negative effects on a survivor's social and occupational functioning. This book has been organized towards that specific approach, by compiling the scientific work of very well-known scientists from all over the world. The psychological victimization of sexual assault, the physiological aspect of sexual abuse and the different attitudes in coping with sexual assault based on different cultural backgrounds are analyzed. Having in mind that one solution may not necessarily be suitable for all cases, we hope that this book will open a debate on sexual assault for future practice and policy and that it will be a step forward to 'break the silence'.

\title{
How to reference
}

In order to correctly reference this scholarly work, feel free to copy and paste the following:

G. Picherot, N. Vabres, J. Fleury, E. Launay and C. Gras-Leguen (2012). How Do We Recognize Recent Sexual Abuse in Children Less than 10 Years of Age? What Is the Role of Paediatric Wards? Experience in a French Paediatric Hospital, Sexual Abuse - Breaking the Silence, Dr. Ersi Abaci Kalfoğlu (Ed.), ISBN: 978-95351-0425-4, InTech, Available from: http://www.intechopen.com/books/sexual-abuse-breaking-the-silence/howdo-we-recognize-recent-sexual-abuse-in-children-less-than-10-years-of-age-what-is-the-role-of-pe

\section{INTECH}

open science | open minds

\section{InTech Europe}

University Campus STeP Ri

Slavka Krautzeka 83/A

51000 Rijeka, Croatia

Phone: +385 (51) 770447

Fax: +385 (51) 686166

www.intechopen.com

\section{InTech China}

Unit 405, Office Block, Hotel Equatorial Shanghai

No.65, Yan An Road (West), Shanghai, 200040, China

中国上海市延安西路65号上海国际贵都大饭店办公楼405单元

Phone: +86-21-62489820

Fax: +86-21-62489821 
(C) 2012 The Author(s). Licensee IntechOpen. This is an open access article distributed under the terms of the Creative Commons Attribution 3.0 License, which permits unrestricted use, distribution, and reproduction in any medium, provided the original work is properly cited. 